\title{
Who cares what the people think? Revisiting David Miller's approach to theorising about justice
}

Article

Accepted Version

Baderin, A., Busen, A., Schramme, T., Ulas, L. and Miller, D. (2018) Who cares what the people think? Revisiting David Miller's approach to theorising about justice. Contemporary Political Theory, 17 (1). pp. 69-104. ISSN 1470-8914 doi: https://doi.org/10.1057/s41296-017-0136-9 Available at https://centaur.reading.ac.uk/79483/

It is advisable to refer to the publisher's version if you intend to cite from the work. See Guidance on citing.

To link to this article DOI: http://dx.doi.org/10.1057/s41296-017-0136-9

Publisher: Palgrave Macmillan UK

All outputs in CentAUR are protected by Intellectual Property Rights law, including copyright law. Copyright and IPR is retained by the creators or other copyright holders. Terms and conditions for use of this material are defined in the End User Agreement.

www.reading.ac.uk/centaur 
Central Archive at the University of Reading

Reading's research outputs online 


\section{Critical Exchange}

\section{Revisiting the appeal to 'what the people think' in David Miller's theorising about justice}

\section{Introduction}

David Miller's methodological approach to theorising about justice, articulated most explicitly in Principles of Social Justice (1999) but informing his work up to and including the recent Strangers in Our Midst (2016), takes people's existing beliefs and sentiments - 'what the people think' - to play a fundamental constitutive role in the development of normative principles of justice. In this critical exchange, Alice Balderin, Andreas Busen, Thomas Schramme and Luke Ulas subject differing aspects of this methodology to critique, before Miller responds.

Alice Baderin questions the focus on supposed 'fundamental principles' within Miller's account of what the people think. Baderin claims that Miller assumes a hierarchical relationship between persons' fundamental principles and specific political judgements, such that the former can be used as a 'critical mirror' for the latter. Empirical evidence from moral and political psychology, however, does not bear out this hierarchical relationship: for example, rather than working up from fundamental principle to specific judgement, people often seem to 'work backwards', amending their underlying principles to fit their surface judgements. In order to justify the prioritisation of principles within an account of what the people think, Miller must appeal to values external to public opinion.

Andreas Busen proposes an understanding of 'what the people think' that moves beyond a tally of individuals' expressed or demonstrated beliefs (as detailed in the 
empirical studies Miller cites in Principles of Social Justice in particular) to a kind of ‘social knowledge' embedded in a society's practices and institutions. Understood in this way, 'what the people think' can come apart from what given individuals think and express about justice, and it can then be possible to get a firm critical grip on existing individual beliefs without needing to bring in theoretical resources that the society, at a collective level, does not recognise. Busen sees this as a promising route forward, but not one without costs.

Thomas Schramme draws a comparison between Miller and John Stuart Mill in order to highlight the question of what Schramme calls 'external checks' on what the people think. External checks are kinds of normative filters, which might be either formal (concerned with the way public opinion is formed) or substantive (concerned with the content of that opinion). While a methodological approach that appeals to what the people think seemingly ought to employ only formal checks, Schramme sees in Miller's approach an appeal to substantive checks, namely a proper understanding of the 'nature' of particular social relationships. In fact, however, Schramme also understands this substantive check to be successfully incorporated within Miller's approach, because the precise nature of social relationships is not settled definitively by the philosopher, but rather is itself up for public debate.

Luke Ulas suggests that although Miller wants to test his contextualist theory of justice by way of appeal to data concerning what the people think, those data cannot in fact vindicate the theory; they do not necessarily show that 'the people' think contextually about justice, since they are also consistent with disagreement about justice at a fundamental level. Moreover, even if we grant that the data do successfully test Miller's theory, it does not follow that agreement about justice at the level of fundamental principle will lead to agreement at the level of political prescription. If, on the other hand, we countenance the possibility that what the people think is not what is 
contained in Miller's theory, Ulas claims that it would not be clear how to proceed, since Miller's approach seems both to appeal to the constitutive value of what the people think, and to consider there to be independent reasons to think contextually about justice.

In responding, Miller clarifies aspects of his approach, reaffirming his commitment to appeal to what the people think in doing political philosophy, and contrasting this with a flawed but popular 'Armchair View' of the practice, in which philosophers supposedly 'come fully equipped' to determine how political concepts ought to be understood and applied. The Armchair View cannot explain why philosophers disagree, and it cannot protect against biases. While Miller's approach inevitably has an 'Armchair component', in his initial development of a theory of justice, the confirmation of that theory by way of public beliefs avoids the shortcomings of the Armchair View.

\section{Prioritising principles}

Whilst appeals to 'what people think' are commonplace in political theory, systematic treatments of evidence about popular attitudes are rarer - as is deeper reflection on the rationale for engaging with public opinion. David Miller's work is the most notable exception to this pattern (especially Miller, 1999, Chapter 3). ${ }^{1}$ Miller has integrated theorising about social justice with a wide range of data about popular attitudes, as well as discussed at length the value of an empirically informed approach. Here I focus on one key feature of Miller's treatment of public opinion: his claim that political theorists should uncover the 'fundamental principles' that structure common attitudes (Miller, 2002, p. 7). I suggest that the prioritisation of general principles over specific

\footnotetext{
${ }^{1}$ Other important exceptions are Swift, 2003; Walzer, 1994 and 2007; Wolff and de-Shalit, 2007.
} 
judgements plays a key role in Miller's account. Specifically, it seems to offer an appealing strategy for reconciling an interpretive approach to political theory with the critical purpose of theorising about justice. On Miller's account, we can select among the diverse components of public opinion and correct popular errors or biases, whilst remaining within the parameters set by its most basic commitments. In other words, we use public opinion as a critical mirror on itself. This strategy is initially appealing: if we care about public attitudes, surely what should count are people's most general and fundamental beliefs.

However, I argue that Miller's approach is ultimately flawed, because it rests on some problematic empirical assumptions about the shape of public attitudes. Specifically, Miller assumes a hierarchical picture of public opinion in which general principles play a foundational role, when recent work in moral psychology shows that principles, specific judgements and empirical beliefs combine in more complex ways to structure popular attitudes. In prioritising principles over concrete judgements, without regard to empirical evidence about which is psychologically more basic, Miller implicitly relies on normative commitments that are independent of public opinion. The contribution proceeds in three parts. First, I note the complex role that public opinion plays in Miller's work and clarify the focus of this contribution. Secondly, I show how Miller's treatment of public opinion prioritises general principles over specific judgements. Finally, I argue that this move rests on an empirically problematic picture of the shape of popular attitudes.

Three methodological ideas are of central importance to Miller's work and recur throughout his writings on justice and nationality. First, he emphasizes the need for a theory of social justice to be informed by popular attitudes. Secondly, he argues that justice is plural and contextual: the relevant principle will depend on what is being distributed, by whom, and among whom: especially on the kind of relationship that 
exists between the people among whom the distribution is occurring' (Miller, 2007, p. 14). Thirdly, he underlines that a theory of justice should offer feasible prescriptions for real world politics: it must be more than 'a piece of utopian wishful thinking' (Miller, 2003, p. 356. See also Miller, 2013).

Thus Miller's commitment to public opinion is closely intertwined with both his contextual pluralism and a concern with political feasibility. In Principles of Social Justice, the overall direction of argument seems to run from empirical evidence about public opinion to a pluralist account of the demands of justice. In other words, a theory of social justice should take a pluralist form in order to reflect the shape of popular attitudes. However, in more recent work, Miller places less emphasis on public opinion as the foundation for his pluralist theory (for example, Miller, 2007, Introduction). For the purposes of this contribution, I focus on those moments in Miller's work in which the commitment to public opinion is basic. On this account, the role of a theory of social justice is to render popular views consistent and coherent: 'a theory of justice brings out the deep structure of a set of everyday beliefs that, on the surface, are to some degree ambiguous, confused, and contradictory' (Miller, 1999, p. 51). In other words, political theorists are engaged in an essentially interpretive exercise whose parameters are set by popular views.

It is important to distinguish this view of the status of public opinion from an epistemic account, on which public opinion is a useful tool for helping us to get closer to a truth about justice that is ultimately independent of what people think. Instead, the claim is that popular attitudes, suitably corrected or edited, are constitutive of the demands of social justice (on the epistemic/constitutive distinction, see Swift, 2003). This constitutive view can usefully be seen as a member of the broader family of idealising response-dependence theories of moral value. Such theories maintain that moral values are constituted or brought into being by human attitudes or responses. At 
the same time, however, they eschew a crude or simple form of subjectivism, because they insist that only some attitudes or responses count: those formed under specific conditions or free from certain biases or empirical errors (for example, Johnston, 1989).

The promise of Miller's approach lies in combining an interpretive method with the critical stance of theory in relation to prevailing beliefs. But, as with other idealising response-dependence theories, challenges arise in steering this middle course. First, there is a problem of disagreement. Given a complex set of competing ideas about what is just, rather than a singular public opinion, how are we to identify the attitudes that purportedly constitute the correct normative account? Secondly, what are we to say to cases of widespread public support for abhorrent practices such as slavery? If public attitudes fix the demands of justice, on what basis do we identify these attitudes as unjust?

These worries about Miller's account parallel a more general critique of idealizing response-dependence theories that has been formulated in a particularly powerful way by David Enoch (2005). How, Enoch asks, can we motivate the idealisation away from (or selection among) actual attitudes, without implicitly appealing to attitude-independent moral commitments? The most obvious answer is that the idealisation is needed to track the moral facts in a reliable way. However, this epistemic argument is not available to theorists who hold that an agent being disposed to value $\mathrm{X}$ or to regard $\mathrm{X}$ as right or just is what makes $\mathrm{X}$ valuable, right or just. Enoch draws a useful analogy here with using a watch to tell the time:

The reading of the watch tracks the time - which is independent of it - only when all goes well ... So there is reason to make sure - by idealizing - that all goes well...Had the time depended on the reading of my watch, had the reading of my watch made certain time-facts true, there would have been no reason (not this reason anyway) to "idealize" my watch and see to it that the batteries are fully charged. In such a case, whatever the reading would be, that would be the right reading, because that this is the reading would 
make it right. (Enoch, 2005, p. 764)

On the one hand, any account that treats justice as constituted by actual opinion will be extensionally inadequate: it will be insufficiently determinate in many cases and will leave us unable to condemn clearly oppressive practices in contexts in which they are widely endorsed. On the other hand, we need a convincing response to the "why idealise'? challenge that does not illicitly appeal to the ability of the theory to track opinion-independent facts about justice. ${ }^{2}$

Miller is acutely aware of the first horn of this dilemma. Thus he emphasises that political theory should identify ways in which public opinion is incoherent, biased or empirically ill-founded. In particular, he argues that we can select among competing views, and disregard many exclusionary attitudes and practices, by seeking out the fundamental principles that underlie public attitudes. Hence Miller distinguishes on a number of occasions between 'people's concrete judgements about particular institutions or practices...[and] the underlying principles that inform these judgements' (Miller, 2002, p. 7). Crucially, he suggests that it is the latter to which political theorists should attend in developing an account of the demands of justice. This approach, he argues, leaves 'plenty of scope for theories of justice that aim to be coherent, empirically sound and impartial in ways that popular opinion often is not, and yet can be justified to people by appeal to basic beliefs that they already hold (Miller, 2003, p. 353). Thus, as Miller describes the task of developing a theory of justice, we must explore:

...how far differing views about what justice requires can be reconciled by showing that they stem from shared beliefs at a deeper level. My aim in this book is to discover the underlying principles that people use when they judge some aspect of their society to be just or unjust, and then to show that these principles are coherent, both separately and when taken to together. (Miller, 1999, ix).

Here we can see a potentially powerful response to the 'why idealise' challenge. Public

\footnotetext{
${ }^{2}$ See Schramme (this exchange) for related discussion of the problem of 'substantive checks'.
} 
opinion is comprised of multiple elements at different levels. Thus to build a theory that reflects what people really think, we should set aside the more superficial aspects of their views and focus on the most fundamental commitments. In this way, we can resolve the tensions and failings to which public opinion is often subject, by drawing on resources from within public attitudes at a more basic level.

One kind of worry we might have about this approach is that the general principles people espouse are not always morally more attractive than their concrete beliefs and practices (Galston, 1989, p. 125). A second objection, which I focus on here, is that public opinion does not behave in the orderly manner implied by Miller's account. The following passage illustrates Miller's view about the relationship between principles, facts and particular judgments in popular thought: '[Public] beliefs might rest on erroneous factual assumptions - they might apply a principle to a situation thinking that it had features A, B, C, whereas in fact it has features D, E, and F (if they knew that, they would apply a different principle)' (Miller, 2003, p. 352). Similarly, Miller argues that it is important to understand the bases of people's distributive preferences in order to 'help us to predict what will happen if the circumstances alter, or if the people whose behaviour we are trying to analyse receive new information' (Miller, 1999, p. 49). For example, he suggests that if people support inequality on incentive grounds, their beliefs or behaviour are likely to change in response to new information about the effectiveness of incentives, whereas their commitment to inequality will be unmoved if it is based instead on a principle of desert.

Recent work in moral psychology points to two problematic assumptions about the structure of public opinion within the common-sense picture outlined by Miller. First, empirical research challenges the idea that our particular judgements are formed by the application of more general principles to which we are more firmly committed. For example, individuals will recruit either consequentialist or deontological principles 
depending on which supports their preferred moral judgement in a specific case (Ditto et al., 2009, p. 329). Research also shows that individuals sometimes hold firm to their judgements about particular cases, even when the facts of the case are manipulated so that the principles that purportedly justify the judgements no longer apply. For example, when asked about the morality of incest, people tend to say that it is wrong because it leads to harmful consequences. However, when presented with cases of incest that are carefully constructed such that no negative consequences can possibly arise, respondents continue to insist that it is wrong - suggesting that their initial judgement was not, in fact, grounded in the harm-based principle brought forward to justify it (Haidt, Björklund and Murphy, 2010). ${ }^{3}$

Secondly, psychological research undermines Miller's assumption that empirical beliefs intervene between general principles and particular judgements and are susceptible to correction that leads, in turn, to the alteration of the judgements. Instead, our normative judgements often shape both the content of our empirical beliefs and the manner in which we assess the empirical evidence. For example, in one study participants were given a description of a man who walked out of a restaurant without paying - either because he found out his daughter had been in an accident and forgot to pay when leaving in a hurry, or because he tried to get away with stealing when he could. Those presented with the second 'high blame' scenario recalled the price of dinner as significantly higher a week later, with the degree of initial blame impacting the extent to which the size of the bill was exaggerated (Ditto et al., 2009, p. 318). More generally, research has found that people employ less rigorous standards for the evaluation of preference-consistent than preference-inconsistent information (Taber and Lodge, 2006). The crucial implication of this body of evidence is that we cannot

\footnotetext{
${ }^{3}$ I do not endorse Haidt's strongest claims about the general inefficacy of moral reasoning. It is sufficient for the purposes of my argument that moral judgements are sometimes psychologically prior to any more general principles brought forward to justify them. This weaker claim is accepted even by Haidt's critics (see, for example, Jacobsen, 2012).
} 
make any straightforward counter-factual claims about what people would think if they were to appreciate their empirical mistakes. To do so is to neglect the complex ways in which our normative judgements and empirical beliefs are interrelated.

Moral psychologists have drawn a parallel here with the different reasoning patterns of barristers and judges. Miller, in the passages cited previously, assumes that public opinion operates according to a judge-like model, in which we 'work forward' to combine facts and principles in order to reach whatever judgement they seem to support. However, a range of empirical evidence supports the view that we sometimes (unwittingly) 'work backwards', like barristers in an adversarial system: 'people (like attorneys) often have a preference for reaching one conclusion over another, and these directional motivations serve to tip judgment processes in favour of whatever conclusion is preferred' (Ditto et al., 2009, p. 310).

Whilst recent experimental work has focussed primarily on individual ethics, there is evidence of similar patterns of thought in the political domain. For example, studies of US and UK public opinion have consistently revealed widespread hostility towards inheritance tax (IHT). Yet, at the same time, most people strongly espouse the value of equality of opportunity (see, for example, http://www.electionstudies.org). It seems then that many people fail to recognise the policy implications of their own deeper values. According to the model suggested by Miller, we might correct this error in public attitudes, whilst remaining true to public opinion at a deeper level. In other words, there is a sense in which the public should or would support IHT, if they properly understood the significance of their principled commitments. Thus the political theorist can advocate for IHT from within the terms of public opinion. But again empirical evidence challenges this move. For example, participants in a UK qualitative study often began by critiquing IHT on the grounds that it takes money away from people who have worked hard for it all their lives. Yet when this desert claim was 
challenged, by pointing out that inheritances represent an unearned windfall from the point of view of the recipient, participants did not question their position. Instead, they immediately sought some other grounds for their opposition to IHT, for example by shifting from individuals to families as the deserving entity (Lewis and White, 2006, p. 27). This suggests that popular opposition to IHT may be more basic than any more general normative principle brought forward to justify it.

A brief look at some evidence about the behaviour of public attitudes reveals that a hierarchical picture of public opinion - on which superficial concrete judgements are shaped by the application of more basic general principles together with empirical beliefs, and are susceptible to change when these prior beliefs are challenged - is untenable. In some cases there is evidence that the specific judgements are more robustly held. In other instances there simply seems to be no answer as to which of principles or judgements is psychologically more basic (for further discussion, see Sinnott-Armstrong, 2008). This, in turn, suggests a fundamental problem with Miller's initially appealing way of reconciling an interpretive approach to political theory with the critical function of a theory of justice. If a focus on the general principles that structure popular attitudes cannot be supported as an account of what people really think at the deepest level, then how can it be justified - except as a claim about what they ought to think? In consistently prioritising popular principles over judgments, without regard to the question of which is psychologically more basic, Miller implicitly relies on normative commitments that are independent of public opinion.

In a collection of essays exploring David Miller's political philosophy, Bell and de-Shalit nicely capture what Miller is looking for in a theory of justice: 'a pluralistic, critical, and practical theory of justice that navigates between the extremes of complacent relativism and Platonic liberalism' (Bell and de-Shalit, 2003, p. 8). I have argued, however, that 
Miller faces a serious challenge in the way in which he employs public opinion to steer this course. In order to avoid the first extreme, Miller must make idealising moves away from actual opinion. However, he then confronts the problem of adequately motivating this process of idealisation without implicitly appealing to a domain of response-independent 'Platonic' normative facts. I identified a potentially promising response to this challenge in Miller's account of the way in which political theory can work up public opinion, by identifying the principles that underlie sometimes objectionable and often confused particular judgements. Since much of political theory is dedicated to the search for broad theories or principles, it is tempting to approach popular attitudes in a similar way and to locate 'real' public opinion in people's most general commitments. However, I argued that the prioritization of principles rests on a hierarchical picture of the structure of public opinion that is empirically untenable. This leaves Miller unable to justify the priority of public principles, except by appeal to values external to public opinion. A wider message of the paper is that evidence about how people think, as much as what they think, is crucial in addressing the problem of the role of public opinion in political theory.

Alice Baderin

Nuffield College, New Road, Oxford alice.baderin@nuffield.ox.ac.uk

\section{References}

Bell, D. and de-Shalit, A. (2003) Introduction. In: D. Bell and A. de-Shalit (eds.) Forms of Justice: Critical Perspectives on David Miller's Political Philosophy. Lanham: Rowman \& Littlefield Publishers.

Ditto, P., Pizarro, D. and Tannenbaum, D. (2009) Motivated Moral Reasoning. In: D. Bartels, C. Bauman, L. Skitka and D. Medin (eds.) The Psychology of Learning and Motivation, Vol 50. Burlington: Academic Press.

Enoch, D. (2005) Why Idealize? Ethics 115(4): 759-87.

Galston, W. (1989) Community, Democracy, Philosophy: The Political Thought of Michael Walzer. Political Theory 17(1): 119-30.

Haidt, J., Björklund, F. and Murphy, S. (2010) Moral Dumbfounding: When Intuition Finds No Reason. Unpublished manuscript, University of Virginia.

Jacobson, D. (2012) Moral Dumbfounding and Moral Stupefaction. In: M. Timmons (ed) 
Oxford Studies in Normative Ethics. Oxford: Oxford University Press.

Johnston, M. (1989) Dispositional Theories of Value. Proceedings of the Aristotelian Society Supplementary Volume 63: 139-74.

Miller, D. (1999) Principles of Social Justice. Cambridge: Harvard University Press.

Miller, D. (2002) Two Ways to Think About Justice. Politics, Philosophy \& Economics $1(1): 5-28$.

Miller, D. (2003) A Response. In: D. Bell and A. de-Shalit (eds.) Forms of Justice: Critical Perspectives on David Miller's Political Philosophy. Lanham: Rowman \& Littlefield Publishers.

Miller, D. (2007) National Responsibility and Global Justice. Oxford: Oxford University Press.

Miller, D. (2013) A Tale of Two Cities; Or, Political Philosophy as Lamentation. In: D. Miller, Justice for Earthlings: Essays in Political Philosophy. Cambridge: Cambridge University Press.

Sinnott-Armstrong, W. (2008) Abstract + Concrete = Paradox. In: J. Knobe and S. Nichols (eds.) Experimental Philosophy. Oxford, Oxford University Press. 209-30.

Swift, A. (2003) Social Justice: Why Does it Matter What the People Think? In: D. Bell and A. de-Shalit eds., Forms of Justice: Critical Perspectives on David Miller's Political Philosophy. Lanham: Rowman \& Littlefield Publishers.

Taber, C. and Lodge, M. (2006) Motivated Skepticism in the Evaluation of Political Beliefs. American Journal of Political Science 50(3): 755-69.

Wolff, J. and de-Shalit, A. (2007) Disadvantage. Oxford: Oxford University Press.

Walzer, M. (1994) Thick and Thin: Moral Argument at Home and Abroad. Notre Dame, Indiana: University of Notre Dame Press.

\section{What the People Think... and What the Philosopher May Propose Beyond It}

David Miller's political philosophy is marked by a fundamental methodological tension, or maybe even a puzzle. While, on the one hand, Miller holds that political philosophy should be based on the normative beliefs of its addressees (i.e., 'the people'), he simultaneously insists that theories thus conceived are in no way relativistic or conventionalist, but may rather provide a critical perspective on 'what the people think'. How might this possibly work? Drawing on what I take to be methodologically relevant 
aspects of Miller's work, I will first try to show that the puzzle is real and present a detailed account of it, in order to then, in a second step, offer a potential solution to the puzzle. I will end by discussing some methodological consequences resulting from this solution and what to make of them in terms of an overall assessment of Miller's method.

\section{The puzzle}

Let us start with the first part of the puzzle. Miller famously argues for and accordingly identifies his own work as "empirically grounded political philosophy" (Miller, 2008a, p. 553). Probably the most prominent example of this kind of philosophy is his Principles of Social Justice (PSJ), in which he argues "that empirical evidence should play a significant role in justifying a normative theory of justice" (Miller, 1999, p. 51). Yet, the fundamental belief that normative theorising must be informed by empirically verifiable normative beliefs of its addressees can be traced as far back as Social Justice, where he argues that the analysis of people's real-life usage of political concepts represents an "indispensable starting-point" for political theory (Miller, 1976, p. 2). Miller has elaborated on his method by variously distinguishing it from modern-day Platonism (e.g. Miller, 1999, pp. 52-53) or a "Starship Enterprise view" of political philosophy, which holds that normative principles should be formulated by philosophers independently of any particular social or political context (Miller, 2008b, pp. 30-1). Miller seems to reject such methodological positions for at least two reasons. The first concerns the practical force a theory may possess: Miller thinks that political philosophy should "contain ideas that people engaged in real-world politics can take up and act upon” (Miller, 2008b, p. 30) something which principles that abstract entirely from the 'real world' are extremely unlikely to achieve (cf. Miller, 2013, pp. 234-8). The second reason is epistemological: if the principles proposed by the philosopher are supposed to both be derived entirely independently from the real world and still have normative force, he must claim to 
possess "a special kind of knowledge not available to other human beings" (Miller, 2003a, p. 13) - a position Miller finds "even more difficult to defend today than it was in Plato’s time” (Miller, 1999, pp. 52-3).

While all of this underlines why, for Miller, the normative beliefs of the addressees of political philosophy must play a constitutive role with regard to theory-building, it is precisely this methodological stance which has drawn considerable criticism, and in particular charges of relativism or conventionalism (e.g. Swift, 2003). Miller, however - and this leads us to the second part of our puzzle explicitly rejects this criticism and stresses that building a theory on 'what the people think' does not necessarily mean taking into account any beliefs people might hold, but rather only those "adjusted to take account of empirical error, faulty inferences, the distorting effect of self-interest, and so on - that is, the deficiencies that are already commonly understood to produce erroneous beliefs” (Miller, 1999, p. 56; see also Miller, 2003b, pp. 352-357). Similarly, Miller thinks that only those beliefs should be regarded which - somewhat analogous to Rawls's notion of considered judgments - people come to hold after a certain amount of self-reflection (Miller, 1999, p. 56). Even without further discussing these restrictions, they should sufficiently illustrate not only how, according to Miller, a theory informed by people's normative beliefs may still differ considerably from those very beliefs, but also in which way and to what extent such a theory may provide its addressees with a vantage point for critical self-reflection - even though it starts out from their very own normative beliefs. Yet, it seems that Miller wants to argue that in at least two ways political philosophy must be able to go even further beyond 'what the people think'.

For one thing, he insists that the philosopher should be able to identify where people's subjective normative judgments go amiss. In PSJ Miller argues that the principles he identifies in people's beliefs about justice are "appropriate to different 
modes of human relationship", or, in a slightly different formulation, that "it must be possible to show that the principle is fitting or relevant in one social context but not in another" and that this is in fact "more than a merely empirical connection" (Miller, 1999, pp. 32-4, my emphasis). However, unless we assume that the social relationships in question are themselves constituted by people's beliefs about justice (an idea which Miller himself rejects as circular (Miller, 1999, p. 33)), I think this aggravates rather than eases the methodological tension which we started out from: For if Miller wants the connection between principles and social contexts to have the kind of objective normative force implied in the quotes above, he would seem to have to fall back upon an 'external' source of normativity, that is, one that is independent of 'what the people think' (cf. Honneth, 2012 for a similar observation).

Very much the same problem also seems to be present in the second way in which Miller thinks philosophy should be able to transcend 'what the people think'. The philosopher should be able, Miller holds, not only to critically assess the way people apply the principles they currently hold, but also to propose principles that differ from the former (cf. Miller, 2003b, p. 352). Yet, if a theory's normative content is to at least partly transcend the status quo of 'what the people think', we need to know where the respective normativity is coming from. I think that we can safely assume that Miller doesn't want to make an exception and allow for Platonic theorizing here. And, indeed, he seems to hold that even the 'utopian' aspect of theory-building should somehow be constrained by people's existing normative beliefs when he says that "what people now believe about justice tells us a good deal about what they could freely come to believe, especially if we assume that the society they will be living in has many features in common with our own" (Miller, 2003b, p. 352). However, the last part of that quote seems to suggest that here, too, Miller is referring to aspects of the societal context as potential restrictions on which principles - existing or utopian - may be considered as 
'fitting'. Yet, if this is the case, then this raises the same questions as before, namely in what way particular forms of social relationship represent an independent source of normativity, and what this means with regard to the connection between normative principles and those relationships?

\section{The solution?}

When Miller elaborates on the connections between principles and modes of relationship in PSJ, he unambiguously states that they "are not entailments": a particular form of relationship does not logically necessitate a particular principle of justice, but rather makes the latter "fitting" insofar as the specific nature of the relationship "naturally expresses itself" in it (Miller, 1999, p. 35). While I would suggest that we may infer from this that Miller does not ascribe any kind of inherent normativity to particular forms of social relationship, this still does not seem to provide us with a sufficiently clear idea about what precisely makes principles 'fit' them. We may, however, get further clarification from Miller's critical assessment of Jerry Cohen’s (2003) influential claim that any given principle is ultimately derived from a fact-independent principle grounding it. Not surprisingly, Miller's Anti-Platonism leads him to reject this claim, and to instead propose that "even the basic concepts and principles of political theory are fact-dependent" and, more specifically, that political philosophy should take into account and be responsive to "facts of political life - everything we know about human beings and human societies" (Miller, 2008b, pp. 29-31). Rather than holding that facts entail normative principles, Miller suggests, we may characterize the relation between the two as one of "presuppositional grounding": While we cannot go directly from facts to principles, the former can lend plausibility to the latter. Miller illustrates this by way of musing about how we might explain to someone that the fact of human self-consciousness grounds the liberty principle, and suggests: "This is just to remind 
our interlocutor of some very familiar facts about human experience, and to show how it is those facts that bring principles like the liberty principle into play - if the facts were otherwise there would simply be no reason to propose such a principle” (Miller, 2008b, p. 36).

But how do I 'show' someone that a certain fact grounds a principle? In order for me to be able to do so, it would seem that we need to ascribe the same (or at least sufficiently similar) meaning to the fact in question. Take, for instance, the idea that children should not be allowed to work (or at least not nearly the same hours as adults): while we might be able to agree on some sort of objective definition of 'children' (say, anyone below the age of 16), whether or not we also find this claim normatively acceptable will depend on our respective understanding of what being a child means. This understanding, however, is likely to differ considerably depending on the social (and historical) context we are situated in - a conclusion which I gather Miller, given his contextualist outlook, would have to agree with. What this implies, or so I would like to suggest, is that the grounding relation between facts and principles, as Miller presents it, is not objective, but rather best understood itself as the product of social practices, which is 'stored' in social norms and institutions as a kind of 'social knowledge'. As such, it is neither objective nor reducible to subjective beliefs. By socialization through and taking part in social practices, people learn what kind of meaning is ascribed to facts (and thus which principles those facts may ground); yet, surely this doesn't mean that their subjective beliefs will always or necessarily match what they have learned (otherwise there would, among other things, not only be no need to convince others of principles, but also no resources for social change).

How might this help with our initial puzzle? First of all, I would submit that we can now give a more precise account of 'what the people think'. Even though, to my

\footnotetext{
${ }^{4}$ For a recent attempt to develop a theory of justice based on this kind of normative foundation (and the extent to which this represents a Hegelian enterprise), see Honneth, 2014.
} 
knowledge, Miller does not make this distinction himself, I think we may sensibly distinguish between 'what the people think' as some sort of average of people's individual normative beliefs (as expressed in the (quantitative) empirical studies on which Miller draws in PS/) and 'what the people think' as the kind of social knowledge (re-)produced in social practices which I have just elaborated on (which it is certainly more difficult to reveal through (even qualitative) empirical studies which take individuals as their objects of inquiry). If I am correct in my assumption that the kind of grounding Miller posits as the link between facts and principles is situated not on the level of individual beliefs, but on the level of 'what the people think' in the latter sense, this provides us with an explanation as to where Miller gets the normativity from that allows him to go beyond people's existing normative beliefs (which we can now see are just one kind of 'what the people think'): by referring to the social knowledge found in the social practices, norms, and institutions of a society, Miller is able to both criticize individual beliefs and judgments (to the extent that they are incompatible with that social knowledge) and propose principles even beyond the ones people currently hold (to the extent that the social knowledge allows for grounding those principles in given facts) - all without having to bring in 'external' normative criteria.

Let me illustrate this by taking yet another look at the argument Miller presents in PSJ. In claiming that his three principles of justice correspond to three forms of relationship, Miller explains, he is appealing to "norms of appropriateness", and more specifically to what he calls "the 'grammar' of justice"” (Miller, 1999, p. 35). Recall that I have been arguing that what Miller says about the grounding relation between facts and principles also describes his account of the connection between forms of relationship and principles of justice. Now, I submit that what Miller is referring to here is precisely the kind of normative social knowledge I just discussed. Miller also seems to make it clear that the respective norms are not reducible to subjective beliefs, when he 
concedes that "there is not much that can be said to someone who wants to pry justice loose from these moorings [i.e., the "norms of appropriateness"] and present an entirely context-free theory" (Miller, 1999, p. 35). While the philosopher cannot, or so I read Miller here, prove that applying a certain principle to a given form of relationship is objectively wrong, he can point out that insisting on this principle runs contrary to (and insofar comes down to putting oneself outside of) the norms implicit in the social practices and institutions of the society in question.

\section{The cost of the solution}

If any of this is convincing, it might not only provide a plausible explanation of how Miller can both build his theory up from a strictly contextualist vantage point and justifiably claim considerable critical force for it, but thus also make his method more attractive to people who may, in principle, share those two desiderata, but have found them to be incompatible. While I'm personally very sympathetic to Miller's approach, I would like to end here by briefly pointing out three consequences that I think come along with opting for Miller's method. Put differently, I fear that solving our methodological puzzle might come at a cost.

First, by choosing to employ Miller's method the philosopher would seem to have to restrict himself to 'immanent critique' (as it is often ascribed, among others, to Michael Walzer (1987); see Stahl 2013 for a systematic account of 'immanent critique'). To be sure, he would still be perfectly able to criticize and theoretically point beyond the status quo he finds in a given society. However, since, as we have seen, the normative foundation for this is the normativity he finds within the social practices, norms and institutions of the society in question, this would obviously limit the scope of his critique.

Just how much it would limit it depends on how one deals with the second 
consequence I have in mind. While I have not really touched upon this yet in my discussion of Miller's account of how facts ground principles, a lot seems to depend on what kinds of facts we are talking about. Up until now I have taken the different forms of relationship Miller is talking about in PSJ to be 'facts' in the sense that they 'exist' within particular societies. However, Miller himself variously speaks of "modes of human relationship" (Miller, 1999, p. 32; my emphasis), which seems to indicate that the thinks that these 'facts' obtain universally. What difference does this make? Given what we have heard about the grounding relation between facts and principles, it seems plausible to me that facts which obtain universally are at least candidates for grounding universal principles (while facts which only obtain locally are not). This seems to be what Miller has in mind when he distinguishes between objective basic human needs (which on his account ground universal human rights) and much more particular societal needs (which ground local citizenship rights) (Miller, 2007, ch. 7). At first sight this would seem to imply that there are indeed instances where the philosopher's critique can be universal in scope. However, since Miller explicitly holds that facts do not entail principles, a fact's obtaining universally is obviously not sufficient for grounding a principle. Rather, the meaning ascribed to this fact must also be universal that is, there must be some sort of universal social knowledge of the kind I have shown to be essential for Miller's notion of grounding. In contrast to the relatively straightforward task of showing that certain facts obtain universally, determining whether the latter is also the case seems to be much more difficult. Establishing whether there is indeed universal meaning ascribed to certain facts will, for instance, probably involve having to bring in historical, sociological, ethnographic and other perspectives. This is not to say that such an undertaking cannot but fail, but just to point out how much more work is required by opting for Miller's method - in comparison, for example, to doing 'Platonic' philosophy. 
Unfortunately, the third consequence I would like to point out might make things even more complicated. As I have already briefly mentioned, while there might be rather straightforward ways of finding out 'what the people think' on an individual level, it seems to me that establishing the second kind of 'what the people think' I have outlined may be considerably more difficult. As I cannot go any further into this here, I will restrict myself to pointing out what seems to me a particularly difficult aspect. Even if the philosopher finds a way to establish a reliable account of the normative social knowledge within a society, I think that he cannot be agnostic about the way this social knowledge has come about. There is, after all, the very real danger that the currently dominant social norms, institutions and practices result from hierarchical power relations, ideology or the exclusion of certain people or groups - which the philosopher runs the risk of confirming on the level of theory if he takes the social knowledge he finds in a society as his central source of normativity. Of course, this is by no means a new methodological challenge, but has, for instance, always been at the centre of debates about the appropriate method for doing social philosophy (cf. Pedersen, 2012). My point here is simply that this challenge is also one that I don't think can be avoided if one opts for Miller's method.

Once again, I do not think that the costs attached to Miller's method outweigh its benefits. But I think that in choosing our method, we should know what we are getting into - and, given that I have only touched upon what I take to be the implications of Miller's way to doing political philosophy, I am not sure whether I could blame someone for taking the easy (read: Platonic) route, or at least trying to take a shortcut.

Andreas Busen Universität Hamburg, Allende-Platz 1, 20459 Hamburg, Germany andreas.busen@wiso.uni-hamburg.de

\section{References}

Cohen, G.A. (2003) 'Facts and Principles' Philosophy \& Public Affairs 31: 211-45.

Honneth, A. (2012) 'Philosophy as Social Research: David Miller's Theory of Justice, in: 
Honneth, A. The I in We. Studies in the Theory of Recognition, Cambridge: Polity Press.

Honneth, A. (2014) Freedom's Right: The Social Foundations of Democratic Life. New York: Columbia University Press.

Miller, D. (1976) Social Justice. Oxford: Clarendon Press.

Miller, D. (1999) Principles of Social Justice. Cambridge, MA: Harvard University Press.

Miller, D. (2003a) Political Philosophy. A Very Short Introduction. Oxford: Oxford University Press.

Miller, D. (2003b) 'A Response', in: Bell, D.A./De-Shalit, A. (eds.) Forms of Justice. Critical Perspectives on David Miller's Political Philosophy. Lanham, MD: Rowman \& Littlefield.

Miller, D. (2007) National Responsibility and Global Justice. Oxford: Oxford University Press.

Miller, D. (2008a) A Response' Critical Review of International Social and Political Philosophy 11:553-67.

Miller, D. (2008b) 'Political Philosophy for Earthlings', in: Leopold, D./Stears, M. (eds.) Political Theory. Methods and Approaches. Oxford: Oxford University Press.

Miller, D. (2013) A Tale of Two Cities; or, Political Philosophy as Lamentation, in: Miller, D. Political Philosophy for Earthlings, Cambridge: Cambridge University Press.

Pedersen, Jørgen 2012 'Social Philosophy: A Reconstructive or Deconstructive Discipline?' Philosophy and Social Criticism 38: 619-643.

Stahl, Titus 2013 'What is Immanent Critique?', SSRN Working Papers, https://ssrn.com/abstracts $=2357957$

Swift, A. (2003b) 'Social Justice: Why Does It Matter What the People Think?, in: Bell, D.A./De-Shalit, A. (eds.) Forms of Justice. Critical Perspectives on David Miller's Political Philosophy. Lanham, MD: Rowman \& Littlefield.

Walzer, M. 1987 Interpretation and Social Criticism. Cambridge, MA: Harvard University Press.

\section{Mill and Miller: Some thoughts on the methodology of political theory}

In this contribution, I want to discuss David Miller's methodology of political philosophy by way of relating it to ideas of another renowned philosopher, John Stuart Mill. I believe both thinkers share a common purpose, which is to build a more realistic and contextualised political philosophy. They achieve this through including empirical evidence about the normative beliefs of real people in their methodology. I will agree 
with Mill and Miller that normative theory can and indeed should be based on empirical evidence about 'what the people think'. However, I will point out a potential problem when allowing "external checks", as I will call them, to such normative beliefs. External checks are indeed needed for correcting distorted normative beliefs when using them for theoretical purposes of devising a normative theory. But checks might also be used to exclude unwanted substantive normative beliefs. I believe that this could undermine the very methodology of "what the people think." We should include what the people really think, not what we as theorists like people to think.

I would like to be as clear as possible about the philosophical problems and options here, as I will pursue a contentious line of thought. First, it should be obvious that people are themselves not always clear about what they think, especially as regards complex normative issues. In these cases, philosophers might not be able, for pragmatic reasons, to use the suggested methodology. More importantly, philosophers might also want to query what it is that the people really think. I understand this notion to pose a methodological problem of the social sciences. Alternatively, someone might like to introduce a normative requirement into the philosophical model, for instance by saying that what people really think has to be authentic, rational, morally valid, or something the like. However, the more we idealise our model towards what the people should think, the more we lose grip of our starting-point. The quarrel, which is also visible in the pages of this special issue, is similar to debates about different theories in ethics, more objectivist models versus more subjectivist (or mind-dependent) models. I will commit to the latter model without any further argument. I would only like to stress that an objectivist model undermines the very idea of the methodology under scrutiny here. It misses its point, because it does not require reference to what the people think.

In his essay Utilitarianism, John Stuart Mill introduces a test that is supposed to decide between higher and lower pleasures (Mill, 1861: 211). If all or nearly all people 
who are acquainted with two pleasures prefer one over the other, then this is the higher, or more valuable, pleasure of the two. Brushing over several issues here, we might be allowed to say that Mill in effect introduces an empirical test for determining what is good or valuable. He grounds values on facts; facts about the evaluative or normative beliefs of real people. Mill himself uses the test only for a very restricted range of normative matters, namely those that concern basic elements of human happiness. But we can use his idea as a springboard for more general methodological remarks on the use of normative beliefs in the construction of a theory of justice.

The philosophical debate that followed in the aftermath of Mill's considerations mirrors the debate regarding the use of empirical evidence about normative beliefs of "the people", or more specifically about justice beliefs, for generating normative principles. Many philosophers believe it is simply a nonsensical idea to use evidence about what people prefer or value to establish (aspects of) normative theories. This is because these philosophers believe that what people find valuable is quite distinct from 5 what is really valuable. Obviously, a lot hinges on whether the two aspects - what people find valuable and what is valuable - can actually be separated. Once we undermine the belief in a reality of values or of a correct conception of justice, independent of people's evaluations, Mill's methodology looks much less dubious. I

\footnotetext{
${ }^{5}$ Adam Swift, for instance, claims: "If we're thinking about what justice means - really means, not 'means in contemporary debate' - then it is a mistake to give public opinion any deeper or more constitutive role." (Swift, 1993, p. 19 (his emphasis)) Swift agrees with Jerry Cohen here, who similarly, and repeatedly, refers to the "correct principles of justice" (e.g. Cohen, 2000, 131; Cohen, 2011, p. 227).

${ }^{6}$ Cohen himself states that the theory of justice he believes to be correct, i.e. egalitarianism, cannot claim to be more justified than contenders. "(...) I hold the egalitarian views that were instilled in me (...) even though I know that I hold them because they were instilled in me, and that less radical views with no less good epistemic credentials might have been instilled in me" (Cohen 2000, p. 11 (his emphases)). A lot hinges on the phrase "no less good epistemic credentials". If Cohen believes that there can be a correct theory of justice and maintains, at the same time, that even the correct theory does not bear any better epistemic credentials, then he seems to subscribe to a straightforward Platonist theory, where the truth of a normative idea is wholly independent of our epistemic access to it.
} 
will hence pursue the idea of granting findings about what the people think a constitutive role in normative theory, especially in political philosophy (see also Schramme, 2008).

It should be stressed that Mill does not simply refer to facts in order to establish normative conclusions. He rather refers to facts about individual normative beliefs and their prevalence within a community. So he does not draw values from brute facts, but from evaluations of people. There is neither a jump from an 'is' to an 'ought' involved, nor a definition of normative terms, such as "desirable", by reference to non-normative terms, such as "desired.” Desires, for Mill, are evidence that something is desirable.

Mill is also not guilty of another error, namely that of simply taking for granted the normative beliefs of people. He is adamant about excluding preferences based on distortive influences, such as extremely detrimental living conditions. The question of how to filter actual beliefs, as it were, so that they can be transferred into valid evidence for establishing normative ideals, is another big issue I cannot adequately deal with here. At least partly it poses a pragmatic problem for the actual performance of such tests, which has been dealt with to some extent, if perhaps not sufficiently, in the literature on social justice research (Swift, 1999; Liebig \& Lengfeld, 2002), and also in philosophy (Elgin, 1996). But it also poses the problem of how to avoid bias towards certain substantive normative beliefs, as mentioned at the beginning of the essay. This problem will be my concern in the remainder.

To address the widespread objection of a mere conventionalism, criteria for assessing the validity of normative beliefs are required. These criteria can be formal, as suggested by Mill's attempt to exclude distortive influences on, say, the voluntariness or

\footnotetext{
7 The latter would be a naturalistic fallacy, as conceived by Moore; the former would be a violation of Hume's law. Although these are often conflated, they are, strictly speaking, not the same.
} 
authenticity of preferences. External checks could also be substantive, i.e. concerned

9

with the content of a choice. For instance, purely egoistic attitudes could be excluded

from considerations regarding principles of justice. Now, it seems that only formal checks of beliefs would be preferable from the methodological point of view defended here. To determine the normative ideal in advance, before we actually find out what people think, would mean sliding back into an idealised account of theory construction. Checks are only needed to make sure that the empirical data, i.e. normative beliefs, are undistorted. Filters should not be used to establish the alleged "correct" outcome of an empirical test of normative beliefs.

Yet there is a general problem regarding the methodology lurking here: Once we allow any filtering of normative beliefs in order to convert them into considered beliefs for theory construction, we might unwittingly introduce substantive checks, which undermine the very idea of starting from the basis of actual normative beliefs in the first place. I believe it is this problem of external checks - as I want to call it - that occupies David Miller in his account of "what the people think." It is indeed a thorny question whether formal checks can ever be enough for the construction of a plausible normative theory. Perhaps we cannot avoid substantive constraints, at least as far as the very basic elements of a normative theory are concerned, such as basic elements of happiness (Mill) or principles of justice (Miller).

Miller uses 'what the people think' to help establish three different principles of justice: distribution according to equality, according to desert, and according to need. He claims that these principles guide people in different contexts, which vary relative to

\footnotetext{
${ }^{8}$ I take it that formal constraints would include some facts, as well. For instance, if someone believes that we must not inflict pain on sentient beings, but also believes that, say, guinea pigs cannot experience harm, then this would be a formal error, according to my usage of the term.

9 'External' is here used as shorthand for 'external to a subjective point of view'.
} 
different relationships that people have. The principle of equality is found in the context of nation states, desert in instrumental associations, and need in communities that are based on solidarity (Miller, 1999, p. 26ff.).

There is some ambiguity as to how those principles are derived. Either Miller wants to argue that relationships are the basis for principles of justice 10 or that principles are derived from the normative beliefs of people in different contexts, i.e. in 11 different relationships. This ambiguity might actually be desired, as it might well be both influences - lived relationships and justice beliefs - that determine normative principles. Indeed, I do believe the ambiguity is Miller's way of providing external checks on normative beliefs without dismissing them in favour of external criteria 12 alone. He therefore wavers between grounding his normative principles in relationships themselves and normative beliefs about the adequate criteria of distribution in particular relationships or contexts. This is not a shortcoming of his methodology; it is, instead, an important ingredient, because Miller wants to allow for the normative beliefs of people to go wrong.

To check beliefs against relationships is not, however, simply a formal check of beliefs, for example in terms of their voluntariness. If people believe it would be right to, say, allocate medical resources on the basis of desert, they would miss an adequate or fitting criterion, because the basis of healthcare is not to be found in a relationship

\footnotetext{
10 "My aim is to identify the underlying principles of justice that spring directly from the various modes of relationship (...)" (Miller, 1999, p. 26 (his emphasis))

"11 "What grounds do we have for asserting these connections between principles of justice and modes of association? We may begin by looking empirically at the judgments and behaviour of people when they allocate resources in different contexts." (Miller, 1999, p. 34)

${ }_{12}$ "Contextualists claim that there is a relationship of appropriateness between context and principle that is primitive in the sense that it cannot be explained by appeal to some more fundamental principle that applies universally." (Miller, 2002, p. 11)
} 
based on voluntary association. The specific bonds between people that determine principles of justice do not allow for just any possible interpretation, because bonds come with normative boundaries and commitments.

Still, I would argue that Miller's methodology does not imply that there is only one adequate distributive principle per type of relationship. The nature of the relationship provides an external check of subjective beliefs about the best normative principle in this context, but it does not by itself determine these principles. It rather restricts the options by excluding unfitting principles of justice. If checks were more restrictive and would lead to one determinate answer, subjective beliefs of real people would actually be methodologically superfluous. Normative principles, in that case, would be the outcome of the right interpretation of relationships. I have argued that the nature of the relationship rather provides a range, but only a range, of adequate principles, which are selected according to what the people think.

Miller's methodology is therefore not conventionalist, in contrast to what is sometimes asserted. He allows for external checks of normative beliefs, and hence does not simply take normative beliefs for granted when devising his theory. "What the people think" is not fixed once and for all; and is it contestable through a debate about the nature and fittingness of relationships in particular contexts. Hence Miller even shows a way of including substantive external checks of subjective normative beliefs

\footnotetext{
13 "We can discover systematic connections between contexts and principles of justice, so that whenever we find a society that includes human relationships of type $\mathrm{C}$, we can say that those relationships ought to be governed by principle P." (Miller, 2003, p. 350 (my emphases))

14 "We cannot hope to show that a mode of relationship necessitates the use of a certain principle of justice; but we can and must establish more than a merely empirical connection." (Miller, 1999, p. 34 (his emphasis)) To be sure, Miller does occasionally seem to give the nature of a relationship a stronger role: "Once the relationship is defined, we (as competent users of the concept of justice) know the criterion by which dues should be calculated, whether need, desert, equality, or something else." (Miller, 1999, p. 33) "(...) the claims that contextualists make about the contextual validity of principles of justice are themselves objective and universal in character" (Miller, 2002, p. 12). On these occasions, his claim sounds more like a one-particular-principle-per-type-of-relationship point of view.
} 
without undermining the methodology itself - in opposition to the idealising methodology. In his theory, checks are provided by the nature of particular relationships. The interpretation of the nature of different relationships in different contexts is a task for political theorists, if not only for them. This allows for a normative theory to be in conflict with actual normative beliefs and at the same time to claim superiority in normative terms. Still, it would need to be possible to eventually bring people to endorse those theoretical, external viewpoints, as they cannot be established as normatively superior on purely theoretical grounds. Hence there is a (non-vicious)

circularity between subjective evaluations and theoretical considerations.

But how can we ever assess whether actual beliefs or some theoretical consideration are preferable on normative grounds? If people come to endorse the latter, for instance a particular interpretation of a relationship, then there is congruence between normative theory and what the people think; but if they have not, or not yet, endorsed them, on what grounds could a political theorist claim that people's normative beliefs are wrong and ought to be changed? This seems impossible, unless we introduce, yet again, an independent normative criterion, which then seems to amount to a claim about correct normative principles, and we would be back at the point where we departed from idealised and less realistic theories. As long as we stay within a (non-vicious) circle of to-and-fro between subjective beliefs and theoretical claims, I believe we cannot assume the normative superiority of any possible point within this circle. Real errors in normative beliefs, within the methodology put forward here, can only be formal errors, such as coerced attitudes; but there cannot be substantive

\footnotetext{
15 "So, it is a condition for a theory's being valid that it should be possible for people to come to accept it and live according to its principles. Clearly, this is not the same as saying that they must accept it now. But unless one thinks that as far as ethics go people are blank slates on to which more or less anything can be inscribed, it does constrain the content of the theory. Putting the point more positively, what people now believe about justice tells us a good deal about what they could freely come to believe, especially if we assume that the society they will be living in has many features in common with our own." (Miller, 2003, p. 352 (his emphasis))
} 
normative errors. To be sure, this does not prevent normative theorists from criticising people's normative beliefs and trying to convince them otherwise. But I believe taking on this role of a public critic requires a change in purpose: from devising a normative theory that is in line with people's beliefs here and now to a proposal of what people might think, if they follow the political philosopher's suggestion. The latter is a proper task of political theory, but it needs to be distinguished from other tasks. In other words, methodological concerns should be determined by purposes. In this paper, I have defended a view, which I deem to be in line with Miller's methodology, where "what the people think" is the most significant ingredient when establishing normative principles for here and now.

Thomas Schramme University of Liverpool, UK t.schramme@liverpool.ac.uk

\section{References}

Cohen, G. A. (2000) If You're an Egalitarian, How Come You're So Rich? Cambridge, Mass.: Harvard University Press.

Cohen, G. A. (2011) How to Do Political Philosophy. In: On the Currency of Egalitarian Justice, and Other Essays in Political Philosophy. Princeton: Princeton University Press, 225-235.

Elgin, C. Z. (1996) Considered Jugdment. Princeton: Princeton University Press.

Liebig, S. \& Lengfeld, H. (eds.) (2002) Interdisziplinäre Gerechtigkeitsforschung. Zur Verknüpfung empirischer und normativer Perspektiven, Frankfurt: Campus.

Mill, J. S. (1861) Utilitarianism. In: John Robson, gen. ed., Collected Works of J.S. Mill. Vol. X: 203-259, Toronto and London: University of Toronto Press and Routledge.

Miller, D. (1999) Principles of Social Justice, Cambridge, Mass.: Harvard University Press.

Miller, D. (2002) Two Ways to Think About Justice. Politics, Philosophy \& Economics 1 (1): 5-28.

Miller, D. (2003) A Response. In: Bell, D. A. \& de-Shalit, A. (eds.) Forms of Justice. Critical Perspectives on David Miller's Political Philosophy. Lanham: Rowman \& Littlefield, 349-372.

Schramme, T. (2008) On the relationship between empirical research and political theory. Analyse und Kritik30 (2): 613-626.

Swift, A. (2003) Social Justice: Why Does It Matter What the People Think? In: Bell, D. A. \& de-Shalit, A. (eds.) Forms of Justice. Critical Perspectives on David Miller's Political Philosophy, Lanham: Rowman \& Littlefield, 13-28.

Swift, A. (1999) Public Opinion and Political Philosophy: The Relation between Social-Scientific and Philosophical Analyses of Distributive Justice. Ethical Theory and Moral Practice 2: 337-363. 


\section{Are the people thinking what Miller's thinking?}

For David Miller, the job of the political philosopher is to uncover and present back to people "the deep structure of a set of everyday beliefs that, on the surface, are to some degree ambiguous, confused and contradictory," with the aim of producing "a clearer and more systematic statement of the principles that people already hold”. It follows that a theory of justice is to "be tested, in part, by its correspondence with evidence concerning everyday beliefs about justice” (1999 p. 51). ${ }^{16}$ The theory of justice that Miller understands to be embedded in the 'deep structure' of everyday beliefs in the societies with which he is concerned in Principles of Social Justice (hereafter PSJ) is a contextualist one. Miller identifies three relational contexts, each of which have their own distributive principle. A context of solidaristic community (like a family or, says Miller, a nation) brings with it the distributive principle of need; a context of instrumental association (like a market economy) is governed by the principle of desert; and the context of citizenship brings with it the principle of equality. Call this the 'principle-to-context framework'.

The justification for taking an interpretative approach that I will focus on here is an epistemological one. ${ }^{17}$ For Miller, if the philosopher reaches conclusions about the ‘truth' of justice radically divergent from public opinion:

...then we must ask whether the criteria by which the philosopher distinguishes truth from falsehood are the same as those used by the ordinary person. If they are the same, why is there such a radical divergence between the philosopher's conclusions and those of the ordinary person? If, by contrast, the philosopher appeals to different criteria, what warrant does he have for thinking that they lead to objective truth? How can he

\footnotetext{
${ }^{16}$ But only "in part". I return to this below.

${ }^{17}$ This is not the only justification - another is related to the notion that any principles of justice the philosopher offers should be plausibly ‘action-guiding' (see for example Miller, 2013).
} 
distinguish between a mere conviction that the truth is to be found by the method of inquiry he favours, and a warranted belief that this is the case? (1999, p. 52)

These are rhetorical questions; Miller believes there are no good answers. But do the people in fact think what Miller thinks they think? I will here first suggest that we have reason to at least be doubtful about that. Moreover, even if the people do indeed endorse the principle-to-context framework, there remains room for dispute about what follows from the framework politically. On the other hand, if we suppose that there is in fact a disconnect between what the public believes and what Miller imputes to them, then it is not clear what conclusions about justice should be drawn, because Miller also appears to have independent reasons to prefer his contextualist theory.

In PSJ, Miller refers to empirical data to 'test' the principle-to-context framework as an interpretation of what the people think about justice. But at first blush, there appears to be an obvious problem. Miller appeals to survey data (amongst other things) in which respondents answer in a certain way about, for example, the place of desert in judgements about just distributions. But of course, there is never consensus among the respondents; for every majority that responds one way there is a minority that responds in a different way, however much triangulation of studies is carried out. What then enables the assertion that 'the people' think something? I understand Miller's approach here to be to draw a distinction between levels of disagreement. Although the data evidence disagreement among persons, it does not follow that those persons must be disagreeing about the principle-to-context framework; rather, they might simply be disagreeing about how best to categorise the context at hand, or about which context takes priority, while agreeing in the abstract about which distributive principles rightly apply to which contexts. So, for example, disagreements in the survey data about whether it is okay for an employee to use their influence to secure a job for a relative are said by Miller to evidence disagreement about whether the context that takes 
precedence is the familial context or the context of the instrumental association (1999:

36). The assertion that the principle-to-context framework itself is consistent with public belief then survives. ${ }^{18}$

This however is not the only possible interpretation of the data: an alternative is that people in fact do disagree about the framework itself, and it is that deeper disagreement that explains the divergent responses. The empirical data cannot resolve this issue of their own interpretation. Surveys, for instance, tend merely to ask people to select from given options - we do not thereby learn why they select the option(s) that they do. Qualitative studies, in which participants' thoughts about justice are deeply probed, and which therefore provide more insight, are unfortunately less well represented in the data Miller appeals to. It is possible, then, that genuine deep disagreement about principle is being inappropriately rendered as merely a series of misunderstandings about context, or disagreements about context priority.

One worried about this possibility might additionally wonder why, if what the public thinks rightly plays a constitutive role in determining principles of justice, the empirical exercise does not come first, rather than only at the point at which confirmation of a pre-constructed theory is sought. One reason potentially to worry about the order in which Miller does things is that by the time we get to the hard data, there has already been considerable intellectual investment in the theory to be tested. And indeed, the elements of the theory sketched in PSJ can be, I think, understood to proceed from earlier work such as Market, State and Community (1989): the three elements of that book's title being exemplary of the three contexts of instrumental

\footnotetext{
${ }^{18}$ A second possible response to the variation evident in the data is to begin by accepting the inevitable existence of principled disagreement, and then to make clear that by 'what the people think' is meant 'what the majority think'. This seems to be hinted at when Miller recognises the existence of those with "deviant views" (1999, p. 24), which we might interpret as those whose beliefs about justice do not correspond to the principle-to-context framework. Even if we assume that the number of these deviants is small, however, it's not clear how they should relate to the society they find themselves in: if justice is constituted by what 'the people' think, and yet I do not think the same way, what normative authority does justice have for me?
} 
association, citizenship, and community. None of us is immune to 'motivated reasoning' (see Alice Baderin's contribution to this exchange for discussion): might there be a type of confirmation bias at work in the interpretation of the data, that leads one to consider that that data "stands up" the theory (1999, p. 61), rather than simply fails to falsify it?

Perhaps this thought gets things wrong. Miller may respond that even though it is true that he already had a favoured theory before consulting the 'hard' empirical data in PSJ, this does not mean that that theory was not developed in the first place via a process of social interpretation. Miller is, after all, a person in the world: he can claim to have developed his initial contextualist theory via an ongoing 'soft' interpretation of public beliefs and sentiments, in a more Walzerian vein: from the fact he had a theory before coming to consult the hard data it does not follow that that theory must have been constructed, in a Platonic manner, via a process of abstract reasoning divorced from existing political practice. And since Miller is a person in the world who cannot help but interpret society as it confronts him, reference to the 'hard' empirical data could never, in practice, come first. But while this may all be right, any such response would also seem to amount to recognition that the 'hard' data in fact plays a less important role in the interpretative methodology than advertised, even in PSJ. We should also want to know more about exactly what is involved in the prior, 'soft' process of interpretation that delivers us the theory in the first place but is not explicitly contained within Miller's articulation of his methodology. ${ }^{19}$

Suppose, notwithstanding these concerns, that the principle-to-context framework is indeed an accurate representation of the deep structure of collective public belief. There remains the question of what can properly be said to follow, in terms of specific political recommendations, as an implication of that structure. There is

\footnotetext{
${ }^{19}$ In her review of Strangers in Our Midst, Linda Bosniak notes that the precise method of social interpretation Miller there undertakes is unclear. While he does still "briefly cite" some polling and survey data, there also seems to be a more general and underspecified attempt to "intuit the zeitgeist” (Bosniak, 2017, pp. 96-7).
} 
significant scope for divergence on this secondary question, even assuming agreement at that deeper level. An affinity can be drawn with the justificatory "internalism" of Bernard Williams. For Williams, "A has reason to O only if he could reach the conclusion to O by a sound deliberative route from the motivations he already has" (Williams, 1995, p. 35). Miller may want to say something similar, perhaps: 'Policy O is just for Society A only if it can be shown to be an implication of the deep structure of belief about justice Society A already holds'. As Williams freely admits however, "the deliberative process which could lead from A's present [motivational set] to being motivated to O may be more or less ambitiously conceived" (Williams, 1981, p. 110). But given this variability of 'ambition', any number of differing actions, potentially inconsistent with each other, can seemingly be shown to lie at the end of a "sound deliberative route" from persons' existing motivations (Forst, 2012, pp. 30-31). Because of this, disagreement about what any one person has an internal reason to do seems highly likely, even assuming agreement about the contents of the existing motivational set.

The political implications of the 'deep structure' of public belief can themselves be more or less 'ambitiously' conceived. For instance, both Miller (1983) and Michael Walzer (1989) have endorsed a kind of market socialism. But this is surely not the only possible way to cash out the implications of the purported deep structure of public belief. $^{20}$ Even if you and I both agree that the principle of equality applies to the context of citizenship, and the principle of desert to the marketplace, we might well not agree that market socialism is a necessary implication of the confluence of those two principles; perhaps a cap on top-to-bottom income ratios (something else with which Miller has shown sympathy), even where companies stay in private hands, would be sufficient; or perhaps something even less ambitious might be thought to do the trick.

\footnotetext{
${ }^{20}$ As Brian Barry put it with particular reference to Walzer, "Like it or not ... there is a coherent rationale for the private ownership and control of firms, based on widely diffused ideas about the rights of private ownership" (Barry, 1995, p. 74)
} 
In other words, it is again seemingly quite possible for persons to confront the same 'data' - here, the principle-to-context framework itself - and draw opposing conclusions about it.

What does this mean for the normative status of any first-order political prescriptions Miller makes? One answer is to suppose that at this level, the philosopher does indeed have some privileged epistemic status, and does not need to seek correspondence with what the people think; if, on the other hand, the philosopher remains constrained to work within the frame of 'what the people think', then it would seem to be the case that they should resist making first-order political recommendations, because it is inevitable that the people will not think one coherent thing. Perhaps the best way to conceive of things here, however, is to treat the philosopher as a citizen contributing to political debate like any other, offering their own interpretation of the political implications of the shared deep structure of belief without any pretence or requirement that that interpretation is, or will ever be, shared by 'the people' at large.

But what happens if the deep structure of public belief, as a matter of fact, and as I have suggested is quite possible, does not comprise the principle-to-context framework that Miller has produced? ${ }^{21}$ I noted at the outset that Miller says a theory should be tested "in part" by its correspondence with public belief. He says that "the evidence [about public beliefs] is not decisive from a normative point of view unless we can say something more about why a certain mode of social relationship makes the corresponding principle of justice the appropriate one to use" (1999, p. 34). Part of that 'something more' is the perceived "fittingness" between the context and the principle; an independent normative appraisal. Public beliefs, however well systematised by the philosopher, are not in themselves sufficient to ground justice: we must in addition find

\footnotetext{
${ }^{21}$ Andreas Busen and Thomas Schramme also reflect on this question in their contributions to this critical exchange.
} 
justification for why the content of those beliefs is appropriate. But there is a curiosity here. The normative 'appropriateness' of the link between a given social relationship and a given distributive principle presumably remains even if it did not accord with what the people think. Indeed, as Miller has put it:

...it may turn out that people in [a] society that includes context C fail to apply [principle] P in that context; they may not only fail to govern those relationships in the way that $\mathrm{P}$ demands, they may not even recognise that $\mathrm{P}$ is the appropriate principle to apply. In that case, contextualists should have no hesitation in saying that they [i.e. the people] have got it wrong, that the society is to that extent radically unjust” (Miller, 2003, p. 351, my emphasis)

Contextualists simpliciter might well be able to say this, but how can contextualists who also believe in the constitutive relevance of public belief to justice do so? How can Miller anticipate telling a society that the principle it endorses is "radically unjust" while also being sceptical about philosophers' epistemic capacity to reach normative conclusions at "radical divergence" from those of the ordinary person? (1999, p. 52). One answer for a contextualist to offer might be that it is possible to tell a society it is radically wrong about a given context of justice only when there are other contexts of justice which the society gets right, and that can explain to that society why the context they've got wrong is wrong for them. In that way, Miller could meet his own condition for a valid theory "that it should be possible for people to come to accept it and live according to its principles", where a component of 'possibility' is that persons can be plausibly persuaded to recognise the theory on the basis of the set of beliefs they already hold (Miller, 2003, p. 352).

There could, though, be no correct theory of justice that is completely divorced from what the people think about justice. The reason for this is that, as we have seen, the philosopher is presumed to have no privileged epistemic vantage point - when 
philosophers reach the judgement that what the public believes about justice is comprehensively "wrong", the appropriate reaction is to question the warrant for that judgement. The people are assumed to be competent locators of an appropriate 'deep structure' of justice (even if, as it appears, Miller is willing to allow that they may occasionally go partially wrong); the philosopher enters to make that structure plain, and to explicate its appropriateness. But even if Miller does not think that "what the people think" and what's normatively appropriate will come fully apart in practice, the analytic distinction is illuminating, because if, as I have been suggested he might be, Miller is in fact wrong about what the people think, he seemingly would find himself in a dilemma: on the one hand committed to the notion that the people are essentially the epistemic equals of the philosopher; and on the other hand of the opinion that his contextualist theory of justice is normatively appropriate, when in fact the people endorse something that Miller seemingly considers objectively wrong. It is not clear what the way forward would be in such a scenario - if a correct theory of justice requires both accordance with what the people think and an independent ascription of normative appropriateness, could there here even be correct principles of justice? In the interests of protecting the methodology from having to confront this kind of difficult scenario, there is always reason to believe that it hasn't occurred.

Luke Ulas

Durham University, UK luke.a.ulas@durham.ac.uk

\section{References}

Barry, B. (1995) 'Spherical Justice and Global Injustice', in David Miller (ed.) Pluralism, Justice and Equality. Oxford: Oxford University Press.

Bosniak, L. (2017) 'Immigration Ethics and the Context of Justice', Ethics and International Affairs 31(1), pp. 93-101.

Forst, R. (2012) The Right to Justification: Elements of a Constructivist Theory of Justice. New York: Columbia University Press.

Miller, D. (1999) Principles of Social Justice. Cambridge, MA: Harvard University Press. Miller, D. (2000) Citizenship and National Identity. Cambridge: Blackwell Publishing. Miller, D. (2003) 'A Response', in Daniel Bell and Avnir de-Shalit (eds.) Forms of Justice: Critical Perspectives on David Miller's Political Philosophy. Oxford: Rowman and 
Littlefield. 349-372.

Miller, D. (2013) Justice for Earthlings: Essays in Political Philosophy. Cambridge: Cambridge University Press.

Walzer, M. (1983) Spheres of Justice: A Defence of Pluralism and Equality. New York: Basic Books.

Williams, B (1981) Moral Luck: Philosophical Papers 1973-1980. Cambridge: Cambridge University Press.

Williams, B. (1995) Making Sense of Humanity and other Philosophical Papers, 1982-1993. Cambridge: Cambridge University Press.

\section{Justice beyond the Armchair ${ }^{22}$}

The four contributors to this symposium have raised a challenging set of questions about how to do political philosophy, and specifically about what kind of attention, if any, should be paid to public opinion, or "what the people think." I have wrestled with these questions repeatedly but, as the commentaries reveal, so far failed to provide wholly satisfactory answers. So I welcome this opportunity to try to say more clearly why political philosophy, and especially theories of justice, must draw upon the best available evidence about popular opinion on relevant matters.

To start from a premise that I hope is uncontroversial, I assume that the aim of political philosophy is normative: to provide theories and principles by which existing social institutions, practices and policies can be appraised. This is without prejudice to the question whether the upshot of the appraisal is radical, reformist or conservative: political philosophy can take any of these forms. A successful theory has to meet a number of conditions. If it advocates reform, it needs to show that what is proposed is feasible, isn't morally outrageous, and so forth. But part of the work that needs to be done is conceptual. The theory will recommend arrangements on the grounds that they are legitimate, democratic, just, freedom-enhancing etc. These concepts support

${ }^{22}$ I should like to thank Margaret Moore for helpful comments on an earlier draft of this paper. 
normative conclusions, but they also have descriptive components. So when a political philosopher makes a claim to the effect that justice requires that practice $\mathrm{P}$ be replaced by practice P', this is a claim that needs redeeming. The philosopher has to show that the reasons that favour adopting P' are indeed reasons of justice and not reasons of some other kind.

So how are claims like this to be redeemed? For understandable reasons, philosophers are naturally drawn to what we can call the Armchair View. The Armchair View holds that the philosopher, as a competent user of whichever language he is writing in, comes fully equipped to determine how various concepts are to be applied, and to grasp their descriptive components. It seems to me, however, that this confidence is misplaced. First, what are we to say when different Armchair Views collide? The occupants of the various seats announce that justice means this, freedom means that, and so on, but, as is so often the case, these pronouncements conflict with one another. How can we get beyond the disagreement, as opposed to merely adding to it? Second, political philosophers ought to be more self-reflective than they usually are about the status of the intuitions or 'considered judgements' that they deploy in order to justify their conceptual or normative claims. One reason is that (in Western democracies anyway) their social position biases them in favour of certain views and against others: like other university faculty, their political convictions are overwhelmingly liberal when measured against the views of the population at large. ${ }^{23}$ Another is that philosophers are inevitably tempted to adjust what they take to be their 'pre-theoretical' judgements to fit the theoretical positions they have already arrived at independently. To give one example, few philosophers seem willing to grant desert the fundamental role that it plays in popular conceptions of distributive justice. A likely

\footnotetext{
${ }^{23}$ For some evidence about this in the case of American academics, see Rothman, Lichter and Nevitte, 2005. Among the general public 18\% self-identified as liberal and $37 \%$ as conservative in 1999; for philosophers, the figures were $80 \%$ liberal and $5 \%$ conservative.
} 
explanation is that they have already decided that the concept is problematic, perhaps because they are convinced on metaphysical grounds that individuals cannot be responsible for their decisions and actions in the way that they would need to be for the notion of personal desert to make sense. Now such considerations might indeed justify adopting a strongly revisionary notion of desert, or abandoning the idea all together. But even if this is the right answer to give at the end of the enquiry, it ought not to influence the intuitions from which the philosopher begins. This would be like manipulating the data in order to hold on to a hypothesis to which you were already committed. But sitting in the Armchair, it is going to be very difficult to keep one's primary intuitions uncontaminated by prior theoretical convictions.

The implication I wish to draw is that although political philosophy unavoidably has an Armchair component - I will return to this - there are good reasons for looking beyond the Armchair to vindicate conceptual claims. But where should one look? An initially plausible answer is to focus on shared social practices, treating these as the practical embodiment of the various concepts the philosopher is trying to elucidate. This seems particularly promising in the case of justice. We grasp how justice should best be understood by seeing its principles being deployed in various practical contexts. Rather than ask people what they think, we should look at the rules they have chosen to adopt, for example the rules they apply when deciding how to allocate goods of various kinds amongst themselves.

In his contribution, Andreas Busen proposes moving in this direction, taking a society's 'practices, norms and institutions' as embodying 'social knowledge' that transcends the beliefs of individual members, and is to that extent objective. But he also highlights some potential limitations of such an approach. It will not provide an adequate set of tools to criticize practices that need criticizing - especially since these practices may have been shaped historically by dominant economic or political classes 
in their own interests. I would add a further point: we can’t tell just by looking at a practice what its guiding values are. Consider law as a central social institution. One might expect to learn a great deal about justice by examining legal rules and the principles that lie behind them, and up to a point this is indeed so. But the purpose of law is not simply to deliver justice; it is also guided by considerations of social stability and of economic efficiency. So if one examines tort law, say, as encapsulating a form of social knowledge, there can be different views (as the relevant literature reveals) about how far the practice serves the end of corrective justice, and how far it is concerned with the efficient allocation of costs between plaintiffs and defendants. In making this point, I am of course assuming that we already know roughly what 'corrective justice' means. But if one did not - if one went to tort law to find out what justice meant - then one would get the wrong answer by straightforwardly extrapolating from the practice, in light of the multiple purposes it serves.

Looking instead to public opinion as a source of reliable opinion about concepts like justice appears at first sight to avoid these problems. For, first, people very often use these concepts for critical purposes - a good way to get at how people understand fairness is often through seeing what they regard as unfair, so this avoids the accusation that the concepts that emerge from the beyond-the-Armchair investigation are simply mirrors of the status quo. Second, there is reason to think that it's fairness that concerns them, not some other value, because that's the word they use to express their complaint. However, matters are not so simple. The evidence suggests that people's beliefs about justice, especially their more concrete beliefs, tend to be adaptive in nature. If asked some question about wage fairness, for example, they may take their cue from existing wage differentials as they perceive them. Moreover, the language that people use to express their judgements may not be as tightly disciplined as philosophers would like it to be. For example, philosophers often contrast desert and incentive 
justifications for inequality, but the public may not see the distinction so clearly. So they might agree that policemen, say, deserve to be paid more than shop assistants, but when asked why that was so, explain that no-one would join the police unless their salary was higher.

So it is important to recognize that in order to use public opinion to develop a theory of justice, we must at least start with an embryonic theory that allows us to identify and categorise the relevant beliefs; the Armchair cannot be dispensed with altogether. This is no more of a climb-down that a scientist properly acknowledging that empirical research always begins with a theory that enables the researcher to specify which findings will count as confirming or falsifying the theory; the important thing is that the theory can be falsified by the findings that emerge. In my work on distributive justice, I began by sketching a theory according to which justice was a plural notion, with principles of equality, need and desert being used in different social contexts. And I then looked at a variety of evidence about popular beliefs to see how far these beliefs were indeed a) pluralistic and b) related to contextual variation in the way I had proposed. I was able to show, for example, that in group settings people's views about distributive justice were sensitive to the character of the group they belonged to which can be experimentally manipulated in various ways - and in the direction that the theory predicted. But it was not a case of the theory being straightforwardly confirmed by the evidence. For example, in cases where the subjects are asked to distribute resources on the basis of information about how well the recipients have performed at various tasks, the theory would predict that an (inegalitarian) desert principle would be used. This is indeed what we find, but there is also some pull in the direction of equality, and this needs explaining, since the relevant context is not one in which we would expect that principle to apply (the participants are related only instrumentally). There are various possible explanations, but one that seems promising 
appeals to the idea that equality can serve as a default principle even in contexts where other principles are appropriate. On the one hand, it is simple to use (just divide the quantity of available resources by the number of recipients) and ensures that the allocator cannot be accused of personal bias. On the other hand, in the face of uncertainty about who deserves what, it can serve as an injustice-minimising device (for the reasoning behind this, see Miller, 1999, pp. 234-6). If these conjectures are correct, the theory needs adjusting to accommodate two forms of equality: principled equality, where it is intrinsically important that certain goods be shared equally by everyone, and default equality, where equal distribution is used as a convenient rule of thumb, but one that could readily be trumped by another principle if necessary. ${ }^{24}$

I offer this as an example of how a theory can be open to revision in the face of evidence, despite being used as the framework that guides the search for relevant evidence. But how good is the evidence itself? Both Luke Ulas and Alice Baderin raise critical questions about this. Ulas draws particular attention to the problem of disagreement. If people really do disagree, fundamentally, about what justice requires, how can we use their beliefs to generate support for our theory?

It is important here to analyse the kind of disagreement we may encounter when surveying what the people think. One case will be disagreement that stems from ideological bias. People's more specific beliefs about what's fair - say in relation to pay differentials - are very likely to be influenced by their social position, and the felt need this creates for self-justification. Social position also affects the explanatory stories people tell about worldly success and failure. Here, disagreement could be avoided if we

24

To illustrate, consider the practice of splitting the bill equally at the end of a meal. If I do that with a casual acquaintance, it will be because we both agree that it isn't worth the trouble of calculating what each of us owes; but strictly speaking it would be fairer to do the calculation. That's equality by default. If I do that with my partner, by contrast, it will be because dividing bills equally is part of what it means for us to have an equal relationship. That's principled equality. 
were able to place people behind a Rawlsian veil of ignorance. Since we cannot do that, we need to discount beliefs that are biased in that way, and look at what people say in cases where their own interests are not immediately involved.

People may also disagree over the extent to which social practices should be guided by justice, or by a specific form of justice. Suppose we try to explore how people judge desert by asking them what criteria they would use to allocate prizes among a class of schoolchildren. It is easy to anticipate that some of the respondents might find the very idea of prize-giving objectionable, thinking that it would encourages a competitive attitude that they dislike among the classmates. So they will give 'deviant' responses to the questions we ask, but not because they disagree about what justice would in principle require - they simply think that a particular desert-based form of justice has no place in the classroom. The point here is that although we can ask people questions designed to elicit their sense of justice, we can't guarantee that the answers they give will express that sense; they may respond to some other feature of the scenario we are presenting to them.

So we need to separate normative disagreement in general, which will include disagreement about which principles or values should count for most when practical issues are being decided, from disagreement about justice specifically. The question will then be how much disagreement of the latter kind there actually is once distorting factors such as those mentioned above have been eliminated. This is an empirical matter, but I am tempted to short-circuit the investigation by pointing out that we could not have a concept like justice unless there was broad agreement about how it should be used. ${ }^{25}$ To deny this, you would have to suppose that people continue to speak and

\footnotetext{
${ }^{25}$ When I speak of agreement here, this is meant to encompass the idea that the concrete principles people use depend on the social context in which they are being deployed. This also helps to explain why Armchair philosophers are liable to disagree about the meaning of justice: ignoring contextual pluralism, they promote a particular conception as though it exhausted justice itself, overlooking or ignoring its contextual roots.
} 
argue with each other about justice, while simply failing to recognize that their interlocutors meant something entirely different when they deployed the concept.

The conceptual agreement that is required is agreement at the level of principle, not agreement over practical issues. That is because, when practical issues are being debated, there are usually several values at stake, and much will depend on empirical questions about feasibility, about the likely effects of institutional change, and so. So I agree with Ulas when he says that we cannot move directly from a conceptual account of justice to a political proposal like market socialism. A fully-fledged political theory is likely to incorporate a number of principles as well as an account of the 'basic structure' that will best realise those principles. Getting straight about what justice means is only a first step.

Baderin makes a number of very good points about the way people's thinking about justice questions is actually likely to be structured. She points out in particular that it is a mistake to see their more concrete beliefs as controlled by higher-level principles. However, it is wrong to suppose that when we engage with people's beliefs from a theoretical perspective, we are just attempting to map existing beliefs as accurately as possible, including the sticking points that people won't abandon when it is pointed out to them that they conflict with some principle they say they uphold. What is being attempted by the philosopher is a rational reconstruction of popular beliefs what people would believe if they thought their position through with due regard to logic, consistency, etc. It might be illuminating here to refer to Daniel Kahneman's influential study Thinking Fast and Slow, and his idea that our mental processes can be divided into two systems, one that controls our immediate responses to external stimuli, and another, operating more slowly that 'takes over when things get difficult'. Consider one of Kahneman's examples, the way that framing can affect how we respond to choices that are substantively identical - for example, when the same numerical 
decision is couched either in terms of 'lives saved' or in terms of 'lives lost' (Kahneman, 2012, ch. 34). Our system 2 thinking allows us to see that something is amiss if we find ourselves making inconsistent decisions because of framing effects. Of course the extent to which system 2 controls system 1 will vary from person to person, which also means that there is no guarantee that offering someone a rational reconstruction of their beliefs will persuade them to adopt it. My claim is not that once we get our political philosophy right, all citizens will actually accept it. My (somewhat less ambitious) claim is that they will have reason to accept it, on the assumption that they want to be rational, and that what is being offered makes sense of a considerable part of what they do actually believe.

A question remains about the role that empirical evidence should play in validating the contextual theory of justice itself. The contextual theory holds when distributive decisions have to be made within a group, the appropriate principle to use will depend on the kind of group it is - what type of relationship predominantly obtains between members. For example, in groups whose members are instrumentally related, justice requires that resources should be allocated according to (the relevant kind of) desert, whereas in groups where solidarity prevails, resources should be allocated according to need. Now, what is the status of these claims? They are not analytic. It is not part of the definition of an instrumentally-constituted group that its members enact desert-based distributions. ${ }^{26}$ That their distributive practice takes this form might be a sign that the group is predominantly of such a kind, but that is another question. Nor is the connection between social context and principle of justice one of entailment. I

26

See here the critical appraisal by Axel Honneth, whose charge is that 'the respective practice cannot be described without the use of categories that do not already refer to the corresponding norms of justice' (Honneth, 2012, p. 127). I believe this charge can be rebutted. Although a full description of what it means for a group to be solidaristic in nature, say, will include normative elements, such as the concern that members are expected to show for one another, the description need make no reference to principles of justice specifically. 
cannot see any way of showing that a group within which relationships are of type T must on pain of self-contradiction distribute its resources according to principle P. The claim as I have stated it is that $\mathrm{P}$ is the appropriate principle for the group to use, and this claim is of a type that we are familiar with in other walks of life. For example, when someone behaves towards us rudely or aggressively, there is a range of responses to the behaviour that we regard as appropriate, though we could not demonstrate this to someone who was unable to see it. Now I believe that almost all of us will have the intuitions that bear out these claims about appropriateness, but nevertheless they cannot be self-evident. If matters were so clear cut, it would difficult to understand how philosophers are able to defend (competing) claims about justice that take a universal form - justice should always be understood as equality (suitably defined) or as desert, say, regardless of context. My claim is that philosophers who make these claims are mistaken, but I do not suggest that they are ignoring self-evident truths. So in order to defend contextualism, it is necessary to appeal to empirical evidence about popular opinion in order to establish that there are indeed shared understandings about justice that support it. The idea is to show that people are practising contextualists, not that they themselves have a fully worked-out theory to support the judgements that they make.

This is how I would respond to Thomas Schramme's claim that there is an ambiguity in my methodological approach (though not, he thinks, necessarily a damaging one). '[Miller] wavers between grounding his normative principles in relationships themselves and normative beliefs about the adequate criteria of distribution in particular relationships or contexts'. As a theorist, I claim that different principles of justice are appropriate within different forms of human relationship that's a normative claim - but then I confirm this intuition (which is not self-evident) by looking to see whether it is reflected in the beliefs of the people who actually inhabit 
those relationships. If successful, this approach will avoid the shortcomings of the Armchair View. If my intuitions are idiosyncratic (or class- or gender-biased), looking at the evidence will reveal this.

There is no space here to consider all of the wider issues that this symposium has raised. One concerns the scope of a theory that is developed in the way that I have proposed. Does it apply only to the societies from which the supporting evidence is drawn, or can it also be used as a critical tool with respect to past or present societies whose members appear to understand justice differently? Another is how far the proposed method is specific to justice, and how far it applies to all of the concepts we use for purposes of political evaluation. And yet a third is about the general aim of political philosophy, and whether it is essential, as I believe it to be, that its recommendations should be supported by principles that are accessible to the public, where being accessible means that they connect in the right way to beliefs that people already hold.

\section{References}

Honneth, A. (2012) Philosophy as Social Research: David Miller's Theory of Justice. In: A. Honneth, A. The I in We: Studies in the Theory of Recognition. Cambridge: Polity.

Kahneman, D. (2012) Thinking Fast and Slow. London: Penguin Books.

Miller, D. (1999) Principles of Social Justice. Cambridge, MA; Harvard University Press.

Rothman, S., Lichter, S. and Nevitte, N. (2005) Politics and Professional Advancement Among College Faculty. The Forum, 3 (1), article 2.

David Miller

Nuffield College, Oxford david.miller@nufield.ox.ac.uk 